\title{
PRIORITISING CRITERIA OF MAINTENANCE FOR GREEN ROOF IN HIGH-RISE RESIDENTIALS
}

\author{
Shafikah Saharuddin ${ }^{*}$, Natasha Khalil ${ }^{1}$ and Alia Abdullah Saleh ${ }^{2}$ \\ ${ }^{1}$ Department of Quantity Surveying, Faculty or Architecture, Planning and Surveying, Universiti Teknologi MARA, \\ Perak Branch, Seri Iskandar Campus, Bandar Baru Seri Iskandar, Perak \\ ${ }^{2}$ Department of Building Surveying, Faculty or Architecture, Planning and Surveying, Universiti Teknologi MARA, \\ Perak Branch, Seri Iskandar Campus, Bandar Baru Seri Iskandar, Perak \\ E-mail: * shafikahsaharuddin@gmail.com
}

\begin{abstract}
Numerous problems arise due to the development growth of a country such as the destruction of natural environments and the deficit in green spaces. Thus, in order to overcome these issues, an alternative by implementing green building has been introduced. One of the sustainable approaches in a green building that can be implemented is the green roof. The utilization of a green rooftop over structures has gradually turned into a pattern in urban communities as it gives various advantages to the nation. The objective of the study is to analyse the criteria of maintenance and the rank of each criterion in approaching towards the establishment of best practice of the maintenance for the green roof, by concentrating on high-rise buildings for residential. The data were collected from respondents using the distributed questionnaires through email and via online survey. A total of 30 maintenance managers were drawn as the sample for the study by using purposive sampling technique, where 20 were returned and valid for analysis. Descriptive statistic of mean ranks and standard deviations was adopted for analysis. The most significant criteria in green roof maintenance are drainage, followed by waterproofing, irrigation, water retention and roof slab, based on the result obtained. The result of the study provides a significant improvement to the existing practice in the maintenance practice of the green roof by highlighting its maintenance criteria and key address, as it may assist to standardize the maintenance practice of green roofs in the Malaysian tropical climate.
\end{abstract}

Keywords: Green Roof, Intensive Green Roof, Maintenance, High-rise Residential Buildings, Malaysia

\section{INTRODUCTION}

Since 30 decades ago, the nationwide has pushed for the development growth and wealth generation. This has led to extensive development of building and infrastructure which can be related to urbanization that may raise the economic development as well as the increasing a country's population. The Malaysia's level of urbanization in 2018 has expanded to 76\% (Department of Statistics Malaysia, 2019). It is predicted to rise years by years by looking at the common pattern of urbanization, and by the year of 2030 , it is expected to reach $83 \%$ (United Nations, 2002). The quick growth of urbanization with many development and intensified impervious area, however, has cause threats to human beings and surroundings particularly once it is uncontrolled. The excessive construction due to greater urbanization in the country has led to many environmental problems for example deforestation, destruction of endangered fauna and flora, the decimation of water catchments, urban heat island, and reduces in green spaces. Moreover, it even has put more pressures on land with developers turning their interest on hill land (Ngai, 1998) leaving the earth getting bare from time to time.

According to a study by Yusof \& Johari (2012), the original city area of Kuala Lumpur of 24,222 hectares have decreased to $59.4 \%$ or 14,386 hectares. It includes the grassland, trees, shrubs as well as water bodies. It indicates that the extreme urbanization and construction affect the green areas, whilst creating many other environmental problems. Hence, with the increasing population's growth and the higher rate of urbanization in Malaysia, more than half of the population in the country or equivalent to $76 \%$ are living in the urban areas, where it has led to a great 
demand for housing such as high-rise buildings as well as urban green spaces. To date, the rising rate of urban population is $2.19 \%$ each year (The World Fact Book, 2018). Since the urban areas have been taken up with buildings and infrastructures, hence changing the way houses are being assembled would have an important effect on the whole environmental aspect. As such, the current growth has emerged with several approaches on sustainability with the addition of more green areas. Therefore, one of the promising alternatives for these heavily populated urban areas is through the implementation of green roofs.

However, in Malaysia, the development and application of the green roofs is still lagging behind. Although some buildings declared to be green with the addition of a green roof on top of the buildings, but they are actually not classified as green building as they do not meet certain requirements (Mastor, 2008). One of the factors which contribute to the lack of greenness of a building is the operation and maintenance system. The case of non-functioned green roof to perform its intended purpose due to the lack of maintenance has seems to be another challenges to the green roof application (Ismail et al., 2015). Moreover, a study by Ismail et al., (2012), has also proved that most of the respondents decided that the green roof maintenance is complex and tedious. It shows that the viability of the green roof installation is the main significant factor in Malaysia as the maintenance consideration for the green roof in Malaysia is still mostly unexplored. Today, Malaysia still not have a clear policy framework for the green roof maintenance practice.

Hence, this study focused to determine the existing practice and the significant criteria required in the green roof maintenance by highlighting the high-rise buildings for residential in Malaysia in approaching to the establishment of best practice for the maintenance of the green roof. Moreover, the study will also analyse each maintenance criterion's level of importance for via ranking the listed criteria. Hence, the outcomes and results are to be reviewed and interpreted in order to identify the trend of maintenance practice for the green roof in Malaysia in the future.

\section{OVERVIEW OF GREEN ROOF}

The green roof application on the top of a building in the urban cities have become a trend. This is due to the reason of limitation of lands and the need to preserve the environment. It also offers numerous advantages to the green development growth. A green roof can be found on the top layer of the roof where vegetations are planted, and where a layer of soil and growing medium is necessary in order to help with the growth of vegetation on the roof, as to enhance the performance and features of the roof (Aziz \& Ismail, 2011; McIntyre \& Snodgrass, 2010). In order to eliminate the damaged vegetated footprint happened due to the construction, the green roof is implemented as a means of vegetation or plant material where it is left to grow on the rooftops (Chow \& Abu Bakar, 2016; Fauzi \& Malek, 2013; Getter \& Rowe, 2006). Besides that, a green roof is known as a living roof, vegetated roof or eco-roof (Fauzi et al., 2013).

There are few successful green roofs implementations executed in few buildings in Malaysia, where they acknowledged the implementation of green roof in Malaysia that are still at the primary stage (Ismail et al., 2012). This has made it as a current trend in the city areas such as in the Kuala Lumpur City, where the city has applied green roofs and green facades in the modern contemporary high-rise projects ( Zahir et al., 2014; Zahir et al., 2013). Normally, the green roof can be divided into two distinct categories that is, extensive and intensive green roofs as displayed in Figure 1 and Figure 2 below. However, there are researchers who categorized additional type of green roof as a semi-extensive green roof (Fauzi \& Malek, 2013; Fauzi et al., 2013). It is where 25\% of the area of green roof is covered, and grouped as in between the intensive and extensive green roof system (Fauzi et al., 2013). Table 1 summarized the differences between extensive and intensive green roofs.

Table 1. Differences between Extensive and Intensive Green Roof

\begin{tabular}{cc}
\hline Intensive Green Roof & Extensive Green Roof \\
\hline Require intensive maintenance & Require extensive maintenance \\
Accessible & Inaccessible \\
Require deeper substrate (min $15 \mathrm{~cm})$ & Require shallow substrate (only 2-15 $\mathrm{cm}$ ) \\
Heavyweight (saturated weight between 200 to 500 & Low weight (saturated weight between $60-150$ \\
$\left.\mathrm{~kg} / \mathrm{m}^{2}\right)$ & $\mathrm{kg} / \mathrm{m}^{2}$ ) \\
High cost & Low cost \\
\hline
\end{tabular}

Source: Chow \& Abu Bakar (2016) 


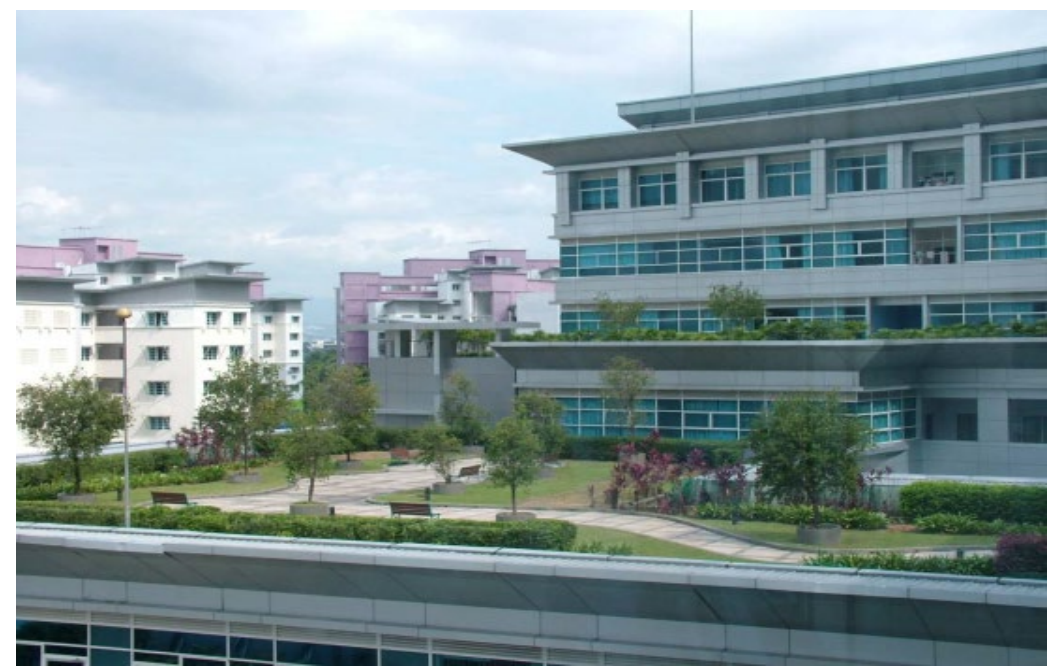

Figure 1. Intensive Green Roof Source: Ismail (2018)

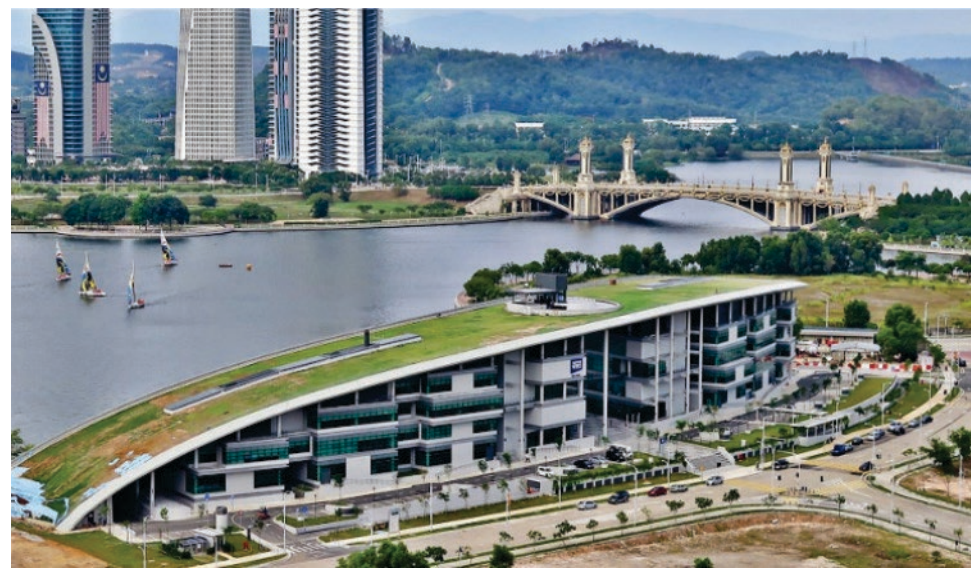

Figure 2. Extensive Green Roof Source: Ismail (2018)

In Malaysia, the basic category of green roof installed is the intensive type of green roof rather than the extensive green roof (Rahman et al., 2013). This is because of the plant selection for the extensive green roof is limited rather than the intensive green roof that lowers the aesthetic value of the green roof. The green roof also contributes numerous advantages for instance, decreasing heat flux, enhancing energy efficiency, optimizing the management of stormwater system, improving carbon sequestration and pollutant trap, along with enhancing building and urban cooling.

\section{OVERVIEW OF MAINTENANCE}

Once built, buildings and its facilities have to be managed so as to continue its function and maintain the values. One of the ways to ensure the functionality of buildings is by practicing sound maintenance principles as well as engaging efficient maintenance programs. The combination of all technical and administrative actions which involve supervision actions in order to sustain an item in or restore it to a state so that it can executes a required function is what maintenance is expressed as by Smith \& Tate (1998). Meanwhile, Idrus et al., (2010); Lam et al., (2010); Mukelas et al., (2012) also clarify that maintenance is a work performed to keep or restore all facility to a suitable and appropriate standard, in order to remain it in good condition and simultaneously prolonging the lifespan 
of the element and the whole building as long as possible by means of significant administrative and managerial expertise.

In short, maintenance can be apprehended as the work that is implemented in order to retain an asset for instance roof, with the purpose of preserving the continuity of use and function to a reasonable level of performance without any unexpected renewal or major repair activities. Traditionally, building maintenance strategies can be categorized into corrective, preventive and condition-based maintenance strategies (Horner et al., 2009; Lee \& Scott, 2009, Seeley, 1987) as in Figure 3 below. A good maintenance practice encourages to preserve the building's value and creates a more enjoyable property as well as contributes pleasure to reside. Nevertheless, an ignored maintenance could result in the damage on the structure which may cause in being legally liable for any damages that may occur.

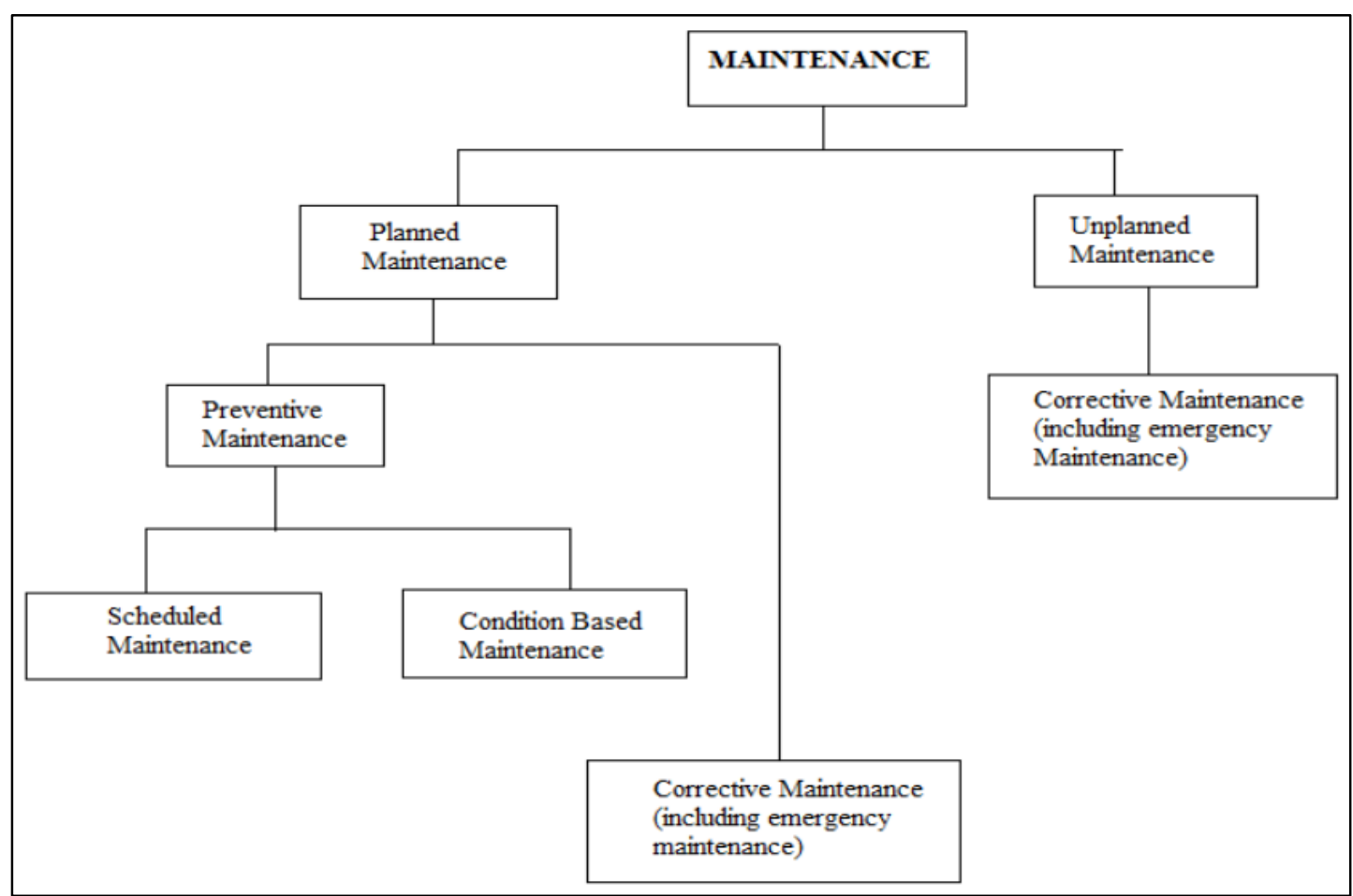

Figure 3. Types of Maintenance

Source: Seeley (1987)

The simplest type of building maintenance strategy is corrective maintenance. As stated by Horner et al. (2009), corrective maintenance tasks are usually done in an ad hoc manner as it is unplanned and occurs when necessary due to failures and breakdowns, or as per requested by the users only. At the same time, Zawawi et al. (2009) further explained that corrective maintenance is managed once a breakdown or a clear error occurred. The corrective maintenance is usually being executed after the building element breaks down or suddenly stop and fails to perform the required functions, where the maintenance is applied afterward. It is also occasionally called as failurebased or unplanned maintenance (Fawaz, 2013).

Concurrently, preventive maintenance strategy is implemented so as to prevent any failure and breakdown from arising by carrying out repair, service or components replacement (Zawawi et al., 2009). "Meanwhile, on the other hand, BS 3811 explains preventive maintenance as the one that is carried out at predetermined intervals or to other prescribed criteria and intended to reduce the likelihood of an item not meeting an acceptable condition". Another study by Kiong \& Akasah (2011), also agreed and further justified that preventive maintenance may reduce the possibility of breakdowns to occur and avoid unexpected catastrophe. This is in order to overcome the weaknesses of corrective maintenance, because this system can eliminate the necessity of the day to day repairing works as well as reducing the amount of separately funded maintenance works. Preventive maintenance is also known as planned maintenance, time-based maintenance, or cyclic maintenance because of the planned maintenance cycle that is carried out according to needs (Fawaz, 2013; Horner et al., 2009). 
Meanwhile, the condition-based maintenance strategy is defined as "Maintenance carried out in response to a significant deterioration in a unit as indicated by a change in a monitored parameter of the unit condition or performance" (Fawaz, 2013; Horner et al., 2009). When there are changes in the condition or performance of an element, which is from a normal to an abnormal circumstance, the condition-based maintenance is executed. Firstly, the part of the elements is monitored by using appropriate condition monitoring tools and techniques in order to check which part of the elements are nearly deteriorating. As reported by Horner et al. (1997), condition-based maintenance's concept is in proving the real condition of every component or item in a building and classifies any changes or performances of a thing by executing maintenance works beforehand.

\section{GREEN ROOF LINK WITH MAINTENANCE}

The maintenance can be said to be a fundamental part of the process after the construction and installation phase when dealing with the green roof system. In Malaysia, the hot and humid weather may affect the use of different types of vegetation along with the operation and maintenance systems. This is due to the usage of a green roof which differs depending on the climate and temperature of certain places. In terms of policies, research done, technology and practice in this area, Malaysia is believed to be far behind when compared to Singapore (Ismail et al., 2010) because the country is in need of incentives and supervision, other than the supports from the government and green building standard organization even though both countries have the same climate and weather. The lack of knowledge and research on maintenance system particularly for tropical climate in the country has led to zero interest amongst the building owners and developers to use the system.

Other than that, when it comes to the maintenance practice on the green roof, it is said to involve a difficult and complex process where it generally leads to a poor maintenance practice. Moreover, as stated in a study by Ismail et al., (2012), it demonstrates that more than half of the respondents or $97 \%$ of respondent come to an agreement that green roof maintenance is difficult and tedious. Consequently, the problems of leakages, mould growth, water ponding, mosquito breeding, the presence of unwanted animals and building defects may occur and thus, shorten the lifespan of the roof and causing more loads to the building structure. Hence, this may eventually contribute to some other unsolved problems. It was also noticed that, the leaking problems on the green roof is hard to detect and need high cost to be repaired, besides the need of appropriate observation rather than a conventional roof. Thus, a proper green roof maintenance is required because it is able avoid leaking and any serious problems which might depreciate the living environments of the urban residents.

\section{METHOD}

This study was purposely performed to ascertain the existing practice and the significant criteria requires in maintaining the green roof maintenance on high-rise buildings for residential in Malaysia. Therefore, each maintenance criterion obtained was ranked according to the level of importance. In order to answer the objectives of the study, a quantitative method was implemented in this study. A set of questionnaires was disseminated to the maintenance managers which have knowledge and experience in carrying out the maintenance works on the intensive green roof of high-rise buildings for residential in Kuala Lumpur by means of purposive sampling. There are 25 highrise residential buildings or projects in Kuala Lumpur, Malaysia which applied intensive green roof that have been identified. Around 19 different companies amongst them were acknowledged to carry out the maintenance on the intensive green roofs. Each company holds one or two management staffs of the maintenance management. Thus, the sampling frame for the study comprised of 30 respondents, which are the maintenance managers who have knowledge and experience in carrying out the maintenance of intensive green roofs in high-rise buildings for residential in Kuala Lumpur, Malaysia. The data of the study is gathered via electronic, which is through email and also via online survey.

There are three (3) sections of close-ended questions and open-ended questions were constructed in the questionnaire set. Section A relates on the respondents and companies' background, whereas Section B concerns about the existing practices and criteria required for the maintenance on the green roof in Malaysia, and Section $\mathrm{C}$ is relating to the rank of criteria for the green roof maintenance, where respondents were to rate the importance of the criteria listed. In the initial part of the questionnaire, the close-ended questions and open-ended questions were adopted. In the meantime, Likert-scale scaling response varied from very important to not important scale, which is from five fixed choice formats that were intended to assess the opinions of the respondents on the level of importance of every maintenance criteria found. Subsequently, in order to produce descriptive statistic, the data were observed using the Statistical Package for the Social Sciences (SPSS) and presented in tabular form and graphs. Out of 30 
questionnaires, there are only 20 returnable questionnaires that were considered valid for the analysis.

\section{RESULT AND DISCUSSION}

\subsection{Respondents' profiles}

20 respondents out of 30 respondents acknowledged to the survey which represent a $67 \%$ response rate. As stated by Creswell (2012), a valid response rate is 50\% and above. Since this study is carried out by using purposive sampling, therefore the number of respondents involved in this study is adequate because the respondents chosen were based on the high-rise residential buildings with an intensive green roof.

Table 2. Summary of Respondents’ Profiles and Company Background

\begin{tabular}{|c|c|c|c|}
\hline \multirow{2}{*}{ Items } & \multirow{2}{*}{ Sub-Items } & \multicolumn{2}{|c|}{$\begin{array}{l}\text { Maintenance Managers } \\
\qquad(\mathbf{n}=\mathbf{2 0})\end{array}$} \\
\hline & & $\begin{array}{l}\text { Frequency } \\
\text { (N) }\end{array}$ & $\begin{array}{c}\text { Percentage } \\
(\%)\end{array}$ \\
\hline \multicolumn{4}{|l|}{ Company particulars } \\
\hline \multirow[t]{4}{*}{ Years of company established } & Below 5 years & 2 & 10 \\
\hline & $5-10$ years & 2 & 10 \\
\hline & $10-15$ years & 5 & 25 \\
\hline & Over 15 years & 11 & 55 \\
\hline Problems or failures occur during the maintenance & Yes & 4 & 20 \\
\hline \multirow[t]{3}{*}{ process of green roof } & No & 1 & 5 \\
\hline & Sometimes & 11 & 55 \\
\hline & $\begin{array}{l}\text { Most of the } \\
\text { time, yes }\end{array}$ & 4 & 20 \\
\hline \multirow[t]{7}{*}{ Types of problems or failures } & Leaks & & \\
\hline & Plant loss & 16 & 80 \\
\hline & Inadequate & 12 & 60 \\
\hline & drainage & 13 & 65 \\
\hline & Soil erosion & 5 & 25 \\
\hline & Slope & 3 & 15 \\
\hline & instability & & \\
\hline$\underline{\text { Respondent particulars }}$ & Yes & 13 & 65 \\
\hline Engaged in the green roof maintenance & No & 7 & 35 \\
\hline \multirow{2}{*}{$\begin{array}{l}\text { Years involved in the green roof maintenance based } \\
\text { on working knowledge and experience in the industry }\end{array}$} & $1-5$ years & 18 & 90 \\
\hline & $6-10$ years & 2 & 10 \\
\hline \multirow{2}{*}{ The importance of green roof maintenance } & Important & 19 & 95 \\
\hline & Not important & 1 & 5 \\
\hline
\end{tabular}

Source: Saharuddin et al. (2019)

Based on Table 2, in regards to the company particulars, the survey tends to come out with the number of years the company has been established. From that, 55\% of the respondents work with the companies which have been recognized for more than 15 years, another $25 \%$ work with the companies that have been operating between 10 to 15 years, whereas $10 \%$ of respondents shared the same percentage for both companies which have been established between 5 to 10 years and below 5 years.

The table also clarifies the frequency and percentage of the occurrence of problems or failures throughout the maintenance works on the green roof. Most of the respondents agreed that the problems or failures do arise during the green roof's operation of maintenance, and the least $5 \%$ of the respondents considered that no problems or failures have took placed. Hence, it can be assumed that problems or failures usually take place in the course of maintaining 
the green roof.

In the meantime, throughout the maintenance process of a green roof, it can be seen that the most frequently occurred problems or failure is leaking, given the highest percentage evaluated by the respondents is $(80 \%)$ which is equal to 16 respondents, followed by insufficient drainage with 13 respondents or $(65 \%)$, then plant loss with 12 respondents $(60 \%)$, soil erosion with five (5) respondents or $(25 \%)$ and the least was for slope instability by $(15 \%)$ which is equal to three (3) respondents.

In regards to the respondents' particulars, $65 \%$ respondents in this study which is more than half of the respondents have involved in the maintenance of green roofs, while another $35 \%$ of the respondents have not once involved in this field. Additionally, majority of the respondents which is $95 \%$ of respondents have involved in the green roof maintenance between 1 to 5 years, whereas another 10\% respondents involved in this field between 6 to 10 years. Consequently, the implementation of a green roof is still new in Malaysia since most of the respondents have less than 5 years' experiences and involvements in the field of the green roof. Furthermore, 95\% of respondents or equals to 19 respondents highlighted that the green roof maintenance is significant, however, only 5\% which is equivalent to one (1) respondent respondend that the green roof maintenance is not important. Therefore, the maintenance of a green roof is indeed very important and requires proper attention especially in today's sustainable construction industry.

\subsection{Assessment of current practices and criteria for green roof maintenance in Malaysia}

The assessment of current practices and maintenance criteria for green roof in Malaysia was conducted and analysed as summarised in Table 3 below. Each of the items is explained in details in each of the sub-topics.

Table 3. Summary of Current Practices and Criteria for Green Roof Maintenance in Malaysia

\begin{tabular}{|c|c|c|c|}
\hline Items & Sub-Items & Frequency (N) & Percentage $(\%)$ \\
\hline \multirow[t]{3}{*}{ Maintenance Strategy } & Preventive Maintenance & 10 & 50 \\
\hline & Corrective Maintenance & 6 & 30 \\
\hline & Condition-Based Maintenance & 4 & 20 \\
\hline \multirow{2}{*}{ Maintenance Procurement Strategy } & Out-source & 15 & 75 \\
\hline & In-house & 5 & 25 \\
\hline \multirow{16}{*}{$\begin{array}{l}\text { Significant Criteria Required for } \\
\text { Green Roof Maintenance }\end{array}$} & Soil Substrate & 13 & 65 \\
\hline & Waterproofing & 17 & 85 \\
\hline & Fertilization & 12 & 60 \\
\hline & Pruning & 12 & 60 \\
\hline & Weed Control & 10 & 50 \\
\hline & Irrigation & 13 & 65 \\
\hline & Root & 10 & 50 \\
\hline & Debris Removal & 10 & 50 \\
\hline & Vegetation & 14 & 70 \\
\hline & Roof Slab & 16 & 80 \\
\hline & Water Retention & 15 & 75 \\
\hline & Pest \& Disease Control & 12 & 60 \\
\hline & Insulation & 8 & 40 \\
\hline & Roof Access & 10 & 50 \\
\hline & Safety & 8 & 40 \\
\hline & Drainage & 17 & 85 \\
\hline
\end{tabular}

Source: Saharuddin et al. (2019) 


\subsubsection{Maintenance strategy}

The study seeks to determine the most adopted maintenance strategy by the maintenance managers for highrise buildings for residential with a green roof. From the survey, $50 \%$ of the respondents which is equal to 10 respondents specified that preventive maintenance is implemented as the main maintenance strategy for the green roof. At the same time, as shown in Table 3 above, six (6) respondents (30\%) chose corrective maintenance, while another $20 \%$ respondents which is equal to 4 respondents implemented condition-based maintenance for the maintenance strategy of the green roof

Moreover, a study by Chua et al., (2018) proved that preventive maintenance strategy is the highly recommended maintenance strategy used by the maintenance workforces of high-rise buildings for residential. This is agreed by Fawaz (2013) mentioning that in Nairobi Country, Kenya, every green buildings implemented a preventive maintenance strategy. Apart from that, historic buildings also implemented a proactive or preventive maintenance strategy for the buildings to be fully preserved and well maintained, instead of other types of maintenance strategy (Zahir et al., 2013). This indicates that the Malaysian building industry is commonly using preventive maintenance strategy which is more worthy to be implemented in the maintenance practice in the country.

\subsubsection{Maintenance procurement strategy}

Basically, the maintenance procurement strategy can be categorized into two, which is out-source maintenance procurement strategy or in-house maintenance procurement strategy. The outcomes of the maintenance procurement strategy applied by the maintenance managers in the study is shown as in Table 3 . It was revealed that more than half of the respondents or $75 \%$ respondents acknowledged on outsourcing the maintenance works of the green roof to other organisations. While the remaining $25 \%$ of the respondents stated that it was in-house projects.

Additionally, a study has proved that the green roof maintenance practice in Malaysia is usually being outsourced to the landscape contractors, while the structural parts of the green roof is still in charge by the managing agent (Ismail et al., 2015). Furthermore, findings in a study by Zawawi et al. (2013) identified that the number 3 ranked non-core facilities which are frequently outsourced or contracted-out by the organisation is landscape services, whereas number one and two were ranked for waste management and security and safety respectively. In the meantime, in Nigeria, most facilities services in high-rise buildings for residential are being outsourced to a standard Service Level Agreement, for instance, sewage treatment, lift management, the swimming pools, and also internet or (Digital Satellite Television) DSTV system as these services require relevant professionals (Olanrele et al., 2013). However, a review by Mohd.Nur \& Musa (2017) informed that majority of the shopping centres in Klang Valley prefer to still practice in-house maintenance procurement strategy for most of the non-core activities. Therefore, this shows that a lot of facilities are commonly out-sourced or contracted-out, particularly the non-core facilities which includes the green roof. However, there are only few buildings which continue to keep all activities in-house. It is due to the facilities which involve experienced and professionals to handle it. Nonetheless, it depends on the management of the building whether to adopt in-house or to out-source the facilities in the building, as there are no prescribed procedures and rules regarding this.

\subsubsection{Criteria in maintaining a green roof}

The maintenance of the facilities needs to be given attention to, in order to sustain the green roof. One of the ways is by considering the significant criteria that may affect the maintenance practice of the green roof. From the survey, Table 3 shows the criteria required for the green roof maintenance in high-rise buildings for residential in Malaysia. The criteria which portray the highest percentage are drainage and waterproofing, where each displays $85 \%$, followed by roof slab (80\%), water retention (75\%) and vegetation (70\%). Meanwhile, the least two criteria being rated by the respondents with only $40 \%$ are insulation and safety.

According to the findings from the survey, it is consistent with the current maintenance practice of green roofs in Malaysia. Implementing preventive maintenance strategy on the maintenance of green roof and outsourcing the maintenance works to other organisations seems to be the relevant practice to be applied in the maintenance practice on the green roof in Malaysia.

\subsection{Rank of criteria in maintaining green roof in Malaysia}

This section is where every criterion recorded in the green roof maintenance in Malaysia were being rated 
by the respondents according to the level of importance for all 16 criteria listed with a five-level numerical likertscale of importance. It ranges from " 1 ", which is equivalent to "not important" until " 5 " which is equivalent to "very important" as shown in Table 4 below (Brown, 2010). The interpretations of the outcomes were then simplified and displayed in descriptive statistics by means of the mean and standard deviation score as per Table 5. This is applied in order to summarise the whole data and information, as well as to convey the results on the distribution in a comprehensive way.

Table 4. Scale of Importance

\begin{tabular}{cc}
\hline Scale Value & Scale \\
\hline 1 & Not important \\
2 & Slightly important \\
3 & Moderately important \\
4 & Important \\
5 & Very important \\
\hline \multicolumn{2}{c}{ Source: Brown (2010) }
\end{tabular}

Table 5. The Rank of Maintenance Criteria for the Green Roof Practice in Malaysia.

\begin{tabular}{|c|c|c|c|c|}
\hline No. & Criteria & Mean & SD & Rank \\
\hline 1. & Drainage & 4.50 & 0.889 & 1 \\
\hline 2. & Waterproofing & 4.40 & 0.940 & 2 \\
\hline 3. & Irrigation & 4.30 & 1.031 & 3 \\
\hline 4. & Water Retention & 4.30 & 1.031 & 4 \\
\hline 5. & Roof Slab & 4.25 & 1.164 & 5 \\
\hline 6. & Insulation & 4.10 & 1.021 & 6 \\
\hline 7. & Soil Substrate & 4.05 & 1.099 & 7 \\
\hline 8. & Vegetation & 4.00 & 0.973 & 8 \\
\hline 9. & Safety & 3.85 & 1.182 & 9 \\
\hline 10. & Roof Access & 3.75 & 1.209 & 10 \\
\hline 11. & Root & 3.70 & 1.218 & 11 \\
\hline 12. & Fertilization & 3.60 & 1.046 & 12 \\
\hline 13. & Pest \& Disease Control & 3.60 & 1.353 & 13 \\
\hline 14. & Debris Removal & 3.55 & 1.050 & 14 \\
\hline 15. & Pruning & 3.50 & 1.100 & 15 \\
\hline 16. & Weed Control & 3.40 & 1.142 & 16 \\
\hline
\end{tabular}

Table 5 illustrates the analysis for the maintenance criteria ranks as evaluated by the respondents concerning the green roof practice in Malaysia,. The table above indicates that all mean values range from the highest mean to the lowest mean, which is between 4.50 and 3.40. As the standard deviation (sd) score values range from 0.889 to 1.142 , hence it represents smaller dispersion on the distribution of data displays where the sd score obtained is less than the mean score. Therefore, the standard deviation shows that all 20 respondents contribute to a consistent level of importance for this study. Henceforth, the data obtained are reliable.

The outcomes also indicate that the most significant criteria in maintaining the green roof is drainage with a mean score of 4.50 and sd value of 0.889 , as ranked by the respondents. It is followed by waterproofing, irrigation, 
water retention and roof slab. Hence, these five criteria were acknowledged as the five core components that are crucial while executing the maintenance on the green roof. The outcome also specifies the criteria with the lowest mean score, which is the weed control with 3.40 and the sd score of 1.142. Despite the fact that it is ranked with the lowest mean score, the criteria too ought to be regarded important while maintaining the green roof.

Based on the obtained mean score, which is between 3.40 to 4.50 , and by indicating to the mean value, it can be inferred that all maintenance criteria ranges from moderately important to very important. None of the mean scores showed that the importance falls in the category of slightly important or not important. In view of that, it can be concluded that each criterion contributes significantly to the maintenance practice on the green roof of high-rise residential buildings in Malaysia. Furthermore, other studies (Coelho et al., 2015; Gedge et al., 2013; Harris, 2014; Lucket, 2009; Raposo \& Pinheiro, 2013; Tolderlund, 2010; Townshend, 2006) also acknowledged all the maintenance criteria ranked in the study. All the criteria were also being clarified to suit the Malaysian tropical climate (Ismail et al., 2015; Kamarulzaman et al., 2014). Thus, this opinion is largely presumed and approved to by literature on maintenance and is also being widely applied in practice.

\section{CONCLUSION}

The study aimed to firstly assesses the opinion in which types of maintenance strategy is regarded as an important part of efficient maintenance programs. Conditions and practice at few high-rise buildings for residential in Malaysia reveal that the maintenance strategy which is commonly being used by the facility manager or maintenance manager for the maintenance on the green roof is the preventive maintenance strategy. Other than that, the green roof maintenance works were generally being outsourced to other organizations, with the purpose of maintaining the current maintenance practice which uses expertise and professionals in Malaysia. The study also discovered 16 criteria which are significant in maintaining the green roof. Amongst the criteria identified in green roof maintenance are soil substrate, waterproofing, fertilization, pruning, weed control, irrigation, root, debris removal, vegetation, roof slab, water retention, pest and disease control, insulation, roof access, safety and drainage. Then, maintenance criteria ranked have proved that the most significant important criteria to be looked in when maintaining the green roof is drainage, followed by waterproofing, irrigation, water retention, roof slab, insulation, soil substrate, vegetation, safety, roof access, root, fertilization, pest and disease control, debris removal, pruning, and weed control. The study contributed to the establishment of best practice maintenance for the green roof, by concentrating on high-rise buildings for residential, as it assists to focus on the significant criteria needed to be highlighted while carrying out the maintenance works on the green roof. Other than that, the outcomes from this study are able to enhance the current body of knowledge on the maintenance of green roof by suggesting the maintenance criteria that is essential and appropriate for the tropical climate. Therefore, in order to enhance the current maintenance practice of green roofs in high-rise buildings for residential in Malaysia, it is hoped that the maintenance team which involved in green roof projects will receive some benefits by performing the maintenance works in a standardized way.

\section{REFERENCES}

Aziz, H. A., \& Ismail, Z. (2011). Design Guideline For Sustainable Green Roof System. In 2011 IEEE Symposium on Business, Engineering and Industrial Applications (ISBEIA), Langkawi, Malaysia Design (pp. 198-203).

Brown, S. (2010). Likert Scale Examples for Surveys.

Chow, M. F., \& Abu Bakar, M. F. (2016). A Review on the Development and Challenges of Green Roof Systems in Malaysia. International Journal of Civil, Environmental, Structural, Construction and Architectural Engineering, 10(1), 16-20.

Chua, S. J. L., Zubbir, N., Ali, A. S., \& Au-Yong, C. P. (2018). Maintenance of High-Rise Residential Buildings. International Journal of Building Pathology and Adaptation, 36(2), 137-151. https://doi.org/10.1108/IJBPA-09-2017-0038

Coelho, A., Silva, C. M., \& Flores-Colen, I. (2015). Green Roofs in Mediterranean Areas : Survey and Maintenance Planning. Building and Environment, 94, 131-143. https://doi.org/10.1016/j.buildenv.2015.07.029 
Creswell, J. W. (2012). Educational Research Planning, Conducting and Evaluating Quantitative and Qualitative Research (4th ed.). Boston: Pearson Education Inc.

Department of Statistics Malaysia. (2019). Population Distribution and Basic Demographic Characteristic Report 2018. Retrieved from https://www.dosm.gov.my

Fauzi, M. A., \& Malek, N. A. (2013). Green Building Assessment Tools : Evaluating Different Tools for Green Roof System. International Journal of Education and Research, 1(11), 1-14.

Fauzi, M. A., Malek, N. A., \& Othman, J. (2013). Evaluation of Green Roof System for Green Building Projects in Malaysia Evaluation of Green Roof System for Green Building Projects in Malaysia. International Journal of Environmental, Chemical, Ecological, Geological and Geophysical Engineering, 7(2), 75-81.

Fawaz, B. (2013). Maintenance Management of Green Buildings in Nairobi County. University of Nairobi.

Gedge, D., Grant, G., Kadas, G., \& Dinham, C. (2013). Creating Green Roofs for Invertebrates: A Best Practice Guide, 1-29. Retrieved from https://www.buglife.org.uk/sites/default/files/Creating Green Roofs for Invertebrates_Best practice guidance.pdf

Getter, K. L., \& Rowe, D. B. (2006). The Role of Extensive Green Roofs in Sustainable Development. HortScience, 41(5), 1276-1285. https://doi.org/10.17776/csj.30292

Harris, M. (2014). The GRO Green Roof Code-Green Roof Code of Best Practice for the UK 2014. United Kingdom.

Horner, R. M. ., El-Haram, M. A., \& Munns, A. . (1997). Building Maintenance Strategy: A New Management Approach. Journal of Quality in Maintenance Engineering, 3(4), 273-280.

Horner, R. M. W., El-Haram, M. A., \& Munns, A. K. (2009). Building Maintenance Strategy : A New Management. Journal of Quality in Maintenance Engineering, 3(4), 273-280. https://doi.org/10.1108/13552519710176881

Idrus, A., Khamidi, F., \& Sodangi, M. (2010). Maintenance Management Framework for Conservation of Heritage Buildings in Malaysia Maintenance Management Framework for Conservation of Heritage Buildings in Malaysia. Modern Applied Science, 4(11). https://doi.org/10.5539/mas.v4n11p66

Ismail, W. Z. W., Abdullah, M. N., Hashim, H., \& Rani, W. S. W. (2018). An Overview of Green Roof Development in Malaysia and A Way Forward. In AIP Conference Proceedings (Vol. 2016, No. 1, p. 020058). AIP Publishing.

Ismail, W. Z. W., Ahmad, S. S., Hashim, A. E., Isnin, Z., \& Ali, I. M. (2010). Perception Towards Green Roof in Malaysia. In Management in Construction Researchers Association 9th Annual Conference and Meeting (MiCRA 2010) (pp. 97-104). MiCRA 2010 - Management in Construction Researchers Association 9th Annual Conference and Meeting.

Ismail, W. Z. W., Ariff, N. R. M., Ahmad, S. S., \& Kamarudin, H. (2015). Green Roof Maintenance towards Sustaining Neighborhood Spaces of High-Rise Residential Developments in Malaysia. American Scientific Publishers, 1-6.

Ismail, Z., Aziz, H. A., Nasir, N. M., Zafrullah, M., Taib, M., \& Alam, S. (2012). Obstacles to Adopt Green Roof in Malaysia. In 2012 IEEE Colloquium on Humanities, Science \& Engineering Research (CHUSER 2012) (pp. 357-361).

Kamarulzaman, N., Hashim, S. Z., Hashim, H., \& Saleh, A. A. (2014). Green Roof Concepts as a Passive Cooling Approach in Tropical Climate- An Overview. In E3S Web of Conferences (Vol. 3, p. 7). https://doi.org/10.1051/e3sconf/20140301028

Kiong, N. B., \& Akasah, Z. A. (2011). Maintenance Factor for Precast Concrete in IBS : A Review. IEEE, 1-6. https://doi.org/10.1109/NatPC.2011.6136352 
Lam, E. W. M., Chan, A. P. C., \& Chan, D. W. M. (2010). Qualitative Survey on Managing Building Maintenance Projects. International Scholarly and Scientific Research \& Innovation, 4(5), 110-114.

Lee, H. H. Y., \& Scott, D. (2009). Overview of Maintenance Strategy, Acceptable Maintenance Standard and Resources From a Building Maintenance Operation Perspective. Journal of Building Appraisal, 4(4), 269 278. https://doi.org/10.1057/jba.2008.46

Lucket, K. (2009). Green Roof Construction and Maintenance. Leeds, UK: The McGraw-Hill Companies Inc.

Mastor, S. H. (2008). A Holistic Concept of Green Building: Potential Application in Malaysia. In International Real Estate Symposium (IRERS). Kuala Lumpur.

McIntyre, L., \& Snodgrass, E. (2010). The Green Roof Manual : A Professional Guide to Design, Installation, and Maintenance. Timber Press, Inc.

Mohd.Nur, N., \& Musa, Z. N. (2017). Defining the Current Practice of Facilities Management Service Delivery in Klang Valley ( KV ) Shopping Centres. Journal of Surveying, Construction and Property (JSCP), 8(1), 115. Retrieved from http://e-journal.um.edu.my/publish/JSCP/

Mukelas, M. F. M., Zawawi, E. M. ., Kamaruzzaman, S. N., Ithnin, Z., \& Zulkarnain, S. H. (2012). A Review of Critical Success Factors in Building Maintenance Management of Local Authority in Malaysia. IEEE, 653657.

Ngai, W. C. (1998). Environmental Hazards Associated With Hill Land Development in Penang Island, Malaysia: Some Recommendations on Effective Management. Disaster Prevention and Management Volume, 7(4), $305-318$

Olanrele, O. O., Ahmed, A., \& Smith, H. O. (2013). Facilities Management Service Delivery in Public and Private High Rise Residential Buildings in Nigeria: A case study of Eko Court Complex and Niger Towers. The 3rd International Building Control Conference 2013, 582-591.

Rahman, S. R. A., Ahmad, H., \& Rosley, M. S. F. (2013). Green Roof: Its Awareness Among Professionals and Potential in Malaysian Market. Procedia - Social and Behavioral Sciences, 85, 443-453. https://doi.org/10.1016/j.sbspro.2013.08.373

Raposo, F. M. F., \& Pinheiro, M. G. C. A. D. (2013). Green Roof Best Practice Guidelines, 1-11.

Seeley, I. H. (1987). Building maintenance. Macmillan Education.

Smith, M., \& Tate, A. (1998). Maintenance Programs Set-up: Application Guide AG1/98. The Building Services Research and Information Association.

The World Fact Book. (2018). CIA: Urbanization. Retrieved from http://www.cia.gov

Tolderlund, L. (2010). Design Guidelines and Maintenance Manual for Green Roofs in the Semi-Arid and Arid West.

Townshend, D. (2006). Study on Green Roof Application in Hong Kong.

United Nations. (2002). World Urbanization Prospects. The 2001 Revision. New York

Yusof, M., \& Johari, M. (2012). Identifying Green Spaces in Kuala Lumpur Using Higher Resolution Satellite Imagery. Alam Cipta, 5(2), 93-106.

Zahir, M. H. M., Raman, S. N., Mohamed, M. F., Jamiland, M., \& Nopiah, Z. M. (2014). The Perception of Malaysian Architects towards the Implementation of Green Roofs : A Review of Practices, Methodologies and Future Research. In E3S Web of Conferences (Vol. 3, p. 01022). EDP Sciences. https://doi.org/10.1051/e3sconf/20140301022

Zahir, M. H., Raman, S. N., Mohamed, M. F., Nopiah, Z. M., \& Jamil, M. (2013). A Discussion on Methodologies to Measure the Perception of Malaysian Architects towards the Implementation of Green Roof System. The 3rd International Building Control Conference 2013, 1-5. 
Zawawi, E. M. A., Kamaruzzaman, S. N., Samad, Z. A., \& Myeda, N. E. (2009). A Quick Survey on Maintenance Management Practice in Malaysian Building Industry. Proceedings 1st Regional Symposium on Sustainable Construction Material and Building System (SUCOMBS) 2009, (2004), 222-228.

Zawawi, Z. A., Ismail, F., Khairuddin, N., Kurdi, M. N., Shuib, M. N., \& Yusof, I. (2013). The Core Services of the Facilities Management Based Company in Malaysia. The 3rd International Building Control Conference $2013,678-682$. 